PETER MLYNARČÍK

Forum Pedagogiczne

Inštitút sv. Jána Bosca

$2015 / 2$

Vysoká škola zdravotníctva a sociálnej práce sv. Alžbety

Bratysława (Stowacja)

\title{
SYSTEM PREWENCYJNY W PRACY EDUKACYJNO- -WYCHOWAWCZEJ NA SŁOWACJI: DZIŚ I JUTRO
}

Streszczenie: Prewencyjny system wychowania Jana Bosko uwidacznia się w stylu życia i metodzie wychowania Rodziny Salezjańskiej. W artykule omówiono stan współczesny i możliwą przyszłość (aktualizację) implementacji tego systemu na Słowacji. Po przedstawieniu obecnej struktury działań oraz personelu Rodziny Salezjańskiej w dalszej części tekstu wymieniono teoretyczne opracowania na temat stosowania systemu prewencyjnego we współczesnych środowiskach życia społecznego. Całość zamyka prezentacja wybranych dokumentów Rodziny Salezjańskiej na temat aktualności systemu prewencyjnego.

Słowa kluczowe: system prewencyjny, Jan Bosko, Rodzina Salezjańska, aplikacja, aktualizacja

\section{Wprowadzenie}

W 2014 roku obchodzono na Słowacji 95. rocznicę otwarcia pierwszej placówki Towarzystwa Salezjańskiego - sanktuarium w Šaštínie koło Trnawy. System prewencyjny w pracy wychowawczej z dziećmi i młodzieżą był znany na Słowacji znacznie wcześniej. Pierwsza zachowana korespondencja autorstwa księdza Bosko skierowana jest do dobrodzieja $\mathrm{z}$ naszego kraju i pochodzi z listopada 1886 roku (Bosco 2012). Praktycznie system prewencyjny zastosowano w wychowywaniu młodzieży po przybyciu salezjanów na Słowację w 1924 roku. Salezjanki (Córki Maryi Wspomożycielki Wiernych) przybyły natomiast na Słowację szesnaście lat później - w 1940 roku. Rok po tym wydarzeniu powołane zostało do istnienia świeckie Stowarzyszenie Maryi Wspomożycielki (ADMA).

Obiecująco rozwijające się dzieło salezjańskie zostało zahamowane przez zmiany polityczne i ustrojowe, polegające na zniesieniu wspólnot religijnych w 1950 roku i wprowadzeniu ścisłej kontroli państwa nad Kościołem katolickim. Był to okres prześladowań, cierpień, ale równocześnie odważnej pracy salezjanów, a później także osób świeckich. Owocem tego okresu pracy podziemnej było powstanie 
i rozbudowa dwóch nowych gałęzi Rodziny Salezjańskiej: Instytutu Ochotniczek Księdza Bosko i Zrzeszenia Współpracowników Salezjańskich. Chociaż salezjańskiego systemu prewencyjnego nie było można formalnie stosować w wychowaniu i edukacji młodych ludzi, to i tak był ciągle obecny w wychowaniu rodzinnym, w grupach młodzieżowych, a także w indywidualnym podejściu wielu pedagogów i nauczycieli.

W 1990 roku nastąpiła zmiana ustroju politycznego. Od tego czasu Rodzina Salezjańska na Słowacji może jawnie działać dla dobra społeczeństwa i oficjalnie oferować prewencyjny system wychowawczy.

Celem niniejszej pracy jest uchwycenie specyfiki systemu prewencyjnego wychowania i edukacji na Słowacji i podjęcie refleksji nad możliwymi sposobami jego aktualizacji zarówno współcześnie, jak i w przyszłości. Popularne zawołanie: „Z księdzem Bosko i czasem” oznacza dla salezjanów i ich współpracowników stałe zaproszenie do aktualizacji systemu prewencyjnego w kontekście wyzwań współczesności (Barillová 2014, s. 55).

Dla uzyskania pełnego obrazu działalności Rodziny Salezjańskiej na Słowacji zostaną najpierw pokazane jej stan personalny, miejsca pracy i obecność w społeczeństwie za pośrednictwem mass mediów. Następnie przedmiotem rozważań będzie charakterystyka systemu prewencyjnego Jana Bosko na Słowacji na podstawie niektórych prac analizujących jego różne aspekty. W końcu ukazana zostanie aktualność tego systemu na podstawie wybranych dokumentów Rodziny Salezjańskiej.

\section{Dane statystyczne na temat Rodziny Salezjańskiej na Słowacji}

W tej części postaram się przedstawić ogólny (statystyczny) obraz Rodziny Salezjańskiej na Słowacji. W tabeli poniżej w kolumnie „Nazwa” wymieniono oficjalne nazwy grup Rodziny Salezjańskiej stosowane na Słowacji. Umieszczone $\mathrm{w}$ nawiasach lata informują, $\mathrm{z}$ jakiego okresu pochodzą dane prezentowane w następnych kolumnach.

Tabela. Grupy Rodziny Salezjańskiej na Słowacji

\begin{tabular}{|c|l|l|l|}
\hline Nazwa & $\begin{array}{l}\text { Liczba } \\
\text { członków }\end{array}$ & $\begin{array}{l}\text { Liczba miejsc } \\
\text { działania }\end{array}$ \\
\hline 1 & $\begin{array}{l}\text { Salezjanie Księdza Bosko - prowincja } \\
\text { Słowacka } \\
\text { Saleziáni don Bosca - Slovenská provincia } \\
\text { (SDB 2014/2015) }\end{array}$ & $218 / 215$ & 24 \\
\hline
\end{tabular}




\begin{tabular}{|c|c|c|c|}
\hline & Nazwa & $\begin{array}{l}\text { Liczba } \\
\text { członków }\end{array}$ & $\begin{array}{l}\text { Liczba miejsc } \\
\text { działania }\end{array}$ \\
\hline 2 & $\begin{array}{l}\text { Córki Maryi Wspomożycielki } \\
\text { Inštitút dcér Márie Pomocnice } \\
\text { (FMA 2013/2015) }\end{array}$ & $80 / 95$ & 13 \\
\hline 3 & $\begin{array}{l}\text { Ochotniczki Księdza Bosko } \\
\text { Dobrovolníčky don Bosca } \\
\text { (VDB 2013) }\end{array}$ & $\begin{array}{l}\text { wszystkich } \\
1308 \text { (po- } \\
\text { łowa SK) }\end{array}$ & - \\
\hline 4 & $\begin{array}{l}\text { Ochotnicy Księdza Bosko } \\
\text { Dobrovolníci s donom Boscom } \\
\text { (CDB 2015) }\end{array}$ & $\begin{array}{l}\text { wszystkich } \\
78(3 \mathrm{SK})\end{array}$ & - \\
\hline 5 & $\begin{array}{l}\text { Stowarzyszenie Salezjanów } \\
\text { Współpracowników } \\
\text { Združenie saleziánov spolupracovníkov } \\
\text { na Slovensku } \\
(\text { ASC 2011/2015) }\end{array}$ & $981 / 1045$ & $28 / 29$ \\
\hline 6 & $\begin{array}{l}\text { Stowarzyszenie Maryi Wspomożycielki } \\
\text { Združenie Márie Pomocnice } \\
\text { (ADMA 2013) }\end{array}$ & 74 & $3(4)$ \\
\hline 7 & $\begin{array}{l}\text { Salezjańskie Stowarzyszenie Młodzieży } \\
\text { Združenie saleziánskej mládeže } \\
\text { (DOMKA 2013) }\end{array}$ & 8500 & 32 \\
\hline 8 & $\begin{array}{l}\text { Stowarzyszenie Młodych } \\
\text { Združenie mladých } \\
\text { (LAURA 2013) }\end{array}$ & 1526 & 15 \\
\hline 9 & $\begin{array}{l}\text { Salezjański Wolontariat Misyjny } \\
\text { Saleziánske misijné dobrovolníctvo } \\
\text { (SAVIO 2005-2015) }\end{array}$ & 500 & 8 \\
\hline 10 & $\begin{array}{l}\text { Stowarzyszenie Byłych Wychowanków } \\
\text { i Wychowanek na Słowacji } \\
\text { Združenie exallievov don Bosca } \\
\text { na Slovensku (2015) }\end{array}$ & ok. 250 & 3 \\
\hline
\end{tabular}

źródło: opracowanie własne

Z powyższej tabeli można wywnioskować, że po roku 199o Rodzina Salezjańska na Słowacji została powiększona o inne grupy i organizacje: Ochotnicy Księdza Bosko powstali w 1994 roku, Stowarzyszenie Byłych Wychowanków i Wychowanek na Słowacji założono w 1999 roku, Salezjańskie Stowarzyszenie Młodzieży DOMKA - w 1991 roku, Stowarzyszenie Młodych LAURA - w 1993 roku, Salezjański Wolontariat Misyjny powstał w 1993 roku, wysyłając pierwszych wolontariuszy 
do Ałdanu (Jakuck), a Stowarzyszenie Obywatelskie do Wspierania Projektów Misyjnych SAVIO - w 2005 roku.

Najliczniejszą grupę Rodziny Salezjańskiej (w sumie 10 o26 członków) stanowią organizacje DOMKA i LAURA, skupiające dzieci i młodzież. Stowarzyszenie Byłych Wychowanków i Wychowanek liczy około 250 zarejestrowanych członków, co stanowi niewielki procent tych, którzy objęci byli wychowaniem salezjańskim. Stowarzyszenie to jest $\mathrm{w}$ fazie ciągłego rozwoju (powstają nowe grupy). Następne miejsca zajmują Stowarzyszenie Salezjanów Współpracowników (1045 członków) i Ochotniczki Księdza Bosko (szacunkowo 600 osób). Nieco mniej liczni są: Salezjański Wolontariat Misyjny (50o wolontariuszy), salezjanie (215), siostry salezjanki (95) i Stowarzyszenie Maryi Wspomożycielki, liczące 74 członków.

Założycielami Salezjańskiego Stowarzyszenia Młodzieży DOMKA są salezjanie, natomiast siostry salezjanki kładły podwaliny pod Stowarzyszenie Młodych LAURA. Miejsc, w których działają organizacje młodzieżowe (DOMKA i LAURA), jest więcej niż placówek, gdzie pracują salezjanie i salezjanki, ponieważ niektóre z organizacji prowadzą współpracownicy salezjańscy i inni świeccy (często byli wychowankowie).

Podsumowując, można stwierdzić, że biorąc pod uwagę liczbę ludności Słowacji ( 5421349 według spisu z dnia 31 grudnia 2014 roku), 972 konsekrowanych członków Rodziny Salezjańskiej (SDB, CMW, VDB, CDB) stanowi o,o18\% ludności słowackiej. Świeckich członków, którzy zetknęli się z pedagogicznym systemem prewencyjnym, jest 1369, co stanowi około o,025\% populacji. Liczba zarejestrowanej młodzieży, która otrzymuje salezjańskie wychowanie prewencyjne, wynosi 10026 osób, co stanowi o,18\% ludności słowackiej (Štatistický úrad slovenskej republiky 2015).

Oprócz wpływu bezpośredniego na społeczeństwo słowackie, Rodzina Salezjańska w propagowaniu systemu prewencyjnego wykorzystuje także mass media. Wśród najważniejszych projektów należy wymienić przede wszystkim "Salmag” - comiesięczny program emitowany przez katolickie stacje telewizyjne TV Lux i TV Noe oraz dostępny na stronie internetowej. Następnie należy wspomnieć czasopismo „Don Bosco dnes” (Ksiądz Bosko Dzisiaj) - dwumiesięcznik wydawany przez Wydawnictwo Księdza Bosko w nakładzie około 15 ooo egzemplarzy. Ponadto od roku 2010 publikowana jest seria książeczek pt. Wiara do kieszeni. Do tej pory zostały wydane 53 tytuły w łącznym nakładzie około 12 ooo sztuk. Opracowane w niej tematy są również prezentowane w formie audycji w Radiu Lumen (Správa o stave provincie 2013).

$\mathrm{Z}$ imprez masowych na uwagę zasługują dwie najważniejsze. Lumen Festiwal promuje muzykę gospel i działania na rzecz formacji chrześcijańskiej, co roku bierze w nim udział około 6000 uczestników (DOMKA Výročná správa 2013). Pielgrzymka relikwii księdza Bosko na Słowacji zgromadziła od 11 do 30 kwietnia 2013 roku w sumie ponad 100 ooo osób, w tym także liczne środowiska, w których salezjanie nie są obecni (Novák 2013). 


\section{Obszary badań w zakresie systemu prewencyjnego Jana Bosko}

W Instytucie Świętego Jana Bosko w Żylinie na Słowacji, należącym do Wyższej Szkoły Służby Zdrowia i Pracy Socjalnej im. św. Elżbiety w Bratysławie, prowadzone są badania nad współczesnością i przyszłością systemu prewencyjnego Jana Bosko. Na podstawie przeprowadzonych i znajdujących się w stanie realizacji projektów można wyróżnić kilka obszarów, w których rozwijana jest refleksja naukowa dotycząca myśli wielkiego wychowawcy młodzieży z Turynu.

\section{Podstawy historyczne}

Kontekst historyczny systemu prewencyjnego Jana Bosko przeanalizował Michal Vojtáš (Vojtáš 2013). W związku z pytaniem o to, jakiej aktualizacji wymagają współczesne czasy, proponuje on odwołanie się do jednej z dominujących cech epoki ponowoczesnej, a mianowicie fragmentaryzacji. Jego zdaniem adekwatna odpowiedź powinna zawierać kilka elementów:

- Życie duchowe: harmonia między duchowością i edukacją. Równowaga między dynamiką otwierania się na świat i dynamiką wierności tożsamości salezjańskiej.

- Intelekt: studium tradycji salezjańskiej w formie naukowej i narracyjno-hagiograficznej.

- Wychowanie: kontakt ze światem młodzieży, z obecnymi modelami i doświadczeniami edukacyjnymi. Międzypokoleniowa bezpośrednia współpraca i dialog w edukacji. Harmonia między treścią i metodą edukacji.

- Projekty: praktyczna, prosta realizacja zrównoważonej aktualizacji systemu prewencyjnego w kodyfikacji i w projekcie. Nie należy tworzyć czegoś więcej, ale stopniowo poddawać harmonizacji istniejące elementy $\mathrm{z}$ innowacjami, tworząc z nich witalną całość, z odwagą i kreatywną wiernością (Vojtáš 2013, s. 51).

Biorąc za podstawę powyższe uwagi w odniesieniu do wychowania i edukacji w duchu salezjańskim na Słowacji, można wyodrębnić następujące wnioski:

- Względnie bogaty ilościowo personel umożliwia eksperymentalne pedagogiczne innowacje, synergię i szersze badania na temat konkretnej realizacji pedagogicznej. Niebezpieczeństwo wynika $z$ indywidualistycznych postaw w projektach i z konfliktów międzypokoleniowych.

- Odejście od sztywnych schematów życia duchowego (duszpasterskiego) umożliwia utrzymanie związku pomiędzy duchowością i edukacją.

- Salezjanie są względnie autonomiczni wobec świata i Kościoła. Istnieje potrzeba zaoferowania zaktualizowanego salezjańskiego modelu edukacji dla Kościoła i społeczeństwa w dialogu z nimi.

- Łączenie duchowości z edukacją znajduje odzwierciedlenie w znaczącej obecności w oratorium, gdzie pracuje się w małych grupach (sportowych, 
artystycznych, religijnych). Potrzebne jest głębsze studium duchowości i pedagogiki dla lepszego zakotwiczenia aktualizacji systemu prewencyjnego. To pomoże poszerzyć horyzonty dla duchowego prowadzenia młodzieży w stylu rodzinnym (Vojtáš 2013, 51-52).

\section{Podstawy filozoficzne}

Antropologia filozoficzna wyjaśnia teoretyczne podstawy systemu prewencyjnego Jana Bosko. Powstał on w okresie, gdy poglądy na temat człowieka prowadziły do rygorystycznego oddzielania płci w procesie wychowania (Fula 2013, s. 139). We współczesności, między innymi dzięki papieżowi Janowi Pawłowi II, przewagę zdobyła antropologia personalistyczna. Oparta jest ona na biblijnej wizji człowieka stworzonego jako „jedność dwojga” na obraz i podobieństwo „jedności Trzech”. Dlatego nowa interpretacja człowieka nie zawęża się do jego indywidualności, ale obejmuje również wzajemność. „Mężczyznę czyni mężczyzną i kobietę kobietą relacja oparta na zasadzie wzajemności: mężczyzna (kobieta) staje się mężczyzną (kobietą), patrząc na kobietę (mężczyznę)” (Fula 2013, s. 140). Spotkanie kobiety i mężczyzny „twarzą w twarz” przybiera konstytutywne, antropologiczne znaczenie. Człowiek w otwartym, bezinteresownym dialogu znajduje samego siebie.

$\mathrm{Na}$ podstawie antropologii personalistycznej system prewencyjny Jana Bosko powinien być stosowany w edukacji w postaci koedukacji, która promuje bazowe środowisko wychowawcze - rodzinę. Wspieranie rodziny, która została osłabiona w czasie zmian społecznych, stanowi jedno z miejsc aplikacji odnowionego systemu prewencyjnego (Fula 2013, s. 142-143).

Uniwersalistyczny wymiar edukacji salezjańskiej jest jednym z istotnych tematów podejmowanych w prezentowanych badaniach. Filozoficznych podstaw sekularyzmu i edukacji poszukuje Andrej Rajský (Rajský 2013) u Hannah Arendt i Benedykta XVI. Spoiwem między wpływem świata i wychowywaniem dzieci (młodych) jest miłość. Miłość do dzieci i do świata. Wspomniany autor pisze: „nasz świat/nasze czasy oddajemy dzieciom, ażeby je kochały, przyjęły, chroniły i przekształcały [...]; zarazem w tym czasie nasze dzieci przygotowujemy do życia w tym świecie/czasie, aby nie były bezradne, żyjące na ich krawędzi, oderwane od korzeni, nieprzystosowane [...], ale żeby świat je mógł wysłuchać i przyjąć" (Rajský 2013, s. 38).

Świat jest tutaj rozumiany jako dzieło twórczej miłości Bożej. Człowiek przez swoją pracę w świecie podobny jest do swego Stwórcy. Tak więc edukacja z miłością i na rzecz miłości do świata i ludzi jest filarem salezjańskiego systemu prewencyjnego. Eksperci obliczyli, że Jan Bosko na 39 sposobów w swoich listach i pismach odmienia stwierdzenie, że jego głównym celem jest wychowanie „dobrego chrześcijanina i uczciwego obywatela” (Braido 1994, cyt. za: Rajský 2013, s. 39). Taka humanistyczno-chrześcijańska wizja wymaga stałego łączenia Ewangelii i kultury poprzez edukację, co powoduje, że niezbędny jest społeczno-polityczny 
wpływ na społeczeństwo. Zastosowanie takiego wymiaru systemu prewencyjnego na Słowacji jest też silnie powiązane z laikatem, ze względu na stosunkowo dużą grupę współpracowników salezjańskich (Rajský 2013, s. 40).

\section{Dydaktyka katechezy}

Specyficzną cechą systemu prewencyjnego Jana Bosko, która znajduje zastosowanie $\mathrm{w}$ katechezie rozumianej szeroko jako wychowanie religijne, jest integracja wiary i życia w procesie osobistego dojrzewania. Współczesną sytuację młodych ludzi określa zsekularyzowany świat bez Boga. W konsekwencji kategorie religijne są dla młodzieży/studentów często puste i niezrozumiałe. W jednym ze swoich opracowań Tibor Reimer proponuje uzupełnienie metod nauczania katechezy o korelatywną dydaktykę symboliczną, która w oparciu o doświadczenia egzystencjalne prowadzi uczniów do nowego poznania ich życia, interpretowanego przez tradycję wiary i odkrywania wiary osobistej (Reimer 2013, s. 80).

Praktyka stosowania dydaktyki korelatywnej wykazała, że takie podejście może być przyczyną niezrównoważonych postaw. Z jednej strony, subiektywne, zsekularyzowane doświadczenie prowadzi uczniów do zbyt abstrakcyjnego pojmowania wiary, co nie świadczy o jej osobistym przyjęciu. Z drugiej natomiast, tradycja religijna bywa zawężana do sztucznych wywodów, które są bezużyteczne w sytuacji życiowej młodzieży. Dlatego Tibor Reimer sugeruje uaktualnienie metody korelatywnej o dedukcyjną korelację metod nauczania. Oznacza to, że efekty związane są z własnym, aktualnym, logicznym doświadczeniem uczniów - w dydaktyce symbolicznej przechodzi się od logicznej dedukcji do prawdopodobnych przyczyn (doświadczeń) zawartych w tradycji wiary (Piaček, Kravčík 1999; Reimer 2013, s. 81).

\section{Pedagogika misyjna}

System prewencyjny Jana Bosko jest stosowany także w edukacji grup zmarginalizowanych społecznie, w szczególności Romów. W oparciu o swoje wieloletnie praktyczne doświadczenie Peter Bešeney wskazuje na następujące zasady takiej pracy:

- Zmiana mentalności w kierunku otwarcia na inne kultury (zmiany społeczno-kulturowe wynikające $\mathrm{z}$ kontaktu $\mathrm{z}$ inną kulturą).

- Zmniejszanie agresji podtrzymywanej przez rodziny i zamknięte środowisko grupy.

- Usuwanie obojętności, dzięki czemu możliwe staje się poznanie siebie i innych, poszanowanie zasad, ogólnych norm społecznych i kulturowych (także zachowanie higieny osobistej).

- Edukacja z aktywnym udziałem uczniów.

- Cierpliwość szanująca rytm życia wspólnoty.

Przy stosowaniu powyższych zasad pożądane jest, aby korzystać z trzech filarów systemu prewencyjnego: rozumu, religii i dobroci (Bešeney 2013, s. 101). 
„System prewencyjny w środowisku Romów wymaga bezgranicznej cierpliwości i samokontroli, wytrwałości i oczekiwania na okazję, na moment, kiedy to wszystko się obróci i zmieni [...]. Wymaga to czasu, który musimy między Romami przemodlić i przecierpieć” (Bešeney 2010, s. 48-49).

\section{Wolontariat}

Organizację czasu wolnego dzieci i młodzieży w dziełach salezjańskich na Słowacji umożliwia praca animatorów - wolontariuszy. Ferdinand Kubík definiuje wolontariat jako „działania prowadzone przez ludzi (głównie młodych) podczas pewnego czasu, bez wynagrodzenia, dla dobra innych" (Kubík 2013, s. 119). Podstawę takiej służby tworzy motywacja, która opiera się na poczuciu solidarności i bezinteresowności, wolnym oddaniu się służbie dla innych, bez dyskryminacji. Działania te zostały uregulowane w ustawie 406/2011 o wolontariacie na Słowacji, która następująco określa warunki, na jakich może być on prowadzony:

- Wykonywanie działalności poza pracą lub obowiązującą nauką szkoloną i bez innych dodatkowych obowiązków.

- Niewykonywanie działalności w placówce (instytucji) publicznej, której jest się członkiem, pracownikiem lub studentem.

- Wykraczanie działalności poza obszar związany z prowadzeniem własnej firmy lub wykonywaniem zawodu.

W ramach wolontariatu na Słowacji młodzież prowadzi razem z salezjanami zajęcia rekreacyjne dla dzieci i młodzieży, pracę misyjną wśród Romów, a ponadto na Ukrainie (w wakacje) lub przez rok w krajach Afryki (Kubík 2013).

\section{Wychowanie prospołeczne w szkołach}

Innym miejscem aplikacji systemu prewencyjnego Jana Bosko na Słowacji jest wychowanie prospołeczne (etyczne) w szkołach. Podstawą takiego zastosowania omawianego systemu jest projekt badawczy Roberta Roche-Olivara (Krížová, Brestovanský 2013), który powstał niezależnie od systemu prewencyjnego. Poszukiwanie prawdy o człowieku i sposobu, w jaki można wypełnić nią swoje życie, prowadzi do zaleceń, które wykazują podobieństwo z systemem prewencyjnym, między innymi:

- Prymat współczującej miłości.

- Poszukiwanie sensu życia w relacjach międzyludzkich.

- Racjonalne podejście do komunikacji, godności osobistej, pozytywnej oceny siebie i innych, empatii itp.

- Życzliwość jako metoda podejścia do uczniów (przyjęcie dziecka takiego, jakim jest, przekazywanie pozytywnych uczuć, przypisywanie pozytywnych cech dzieciom, jasne zasady, ostrożne używanie kar i nagród itp.). 
- Animacja jako nieautorytatywna, stała obecność nauczyciela w grupie uczniów.

- Metoda doświadczeniowa - rozumowe opanowanie doświadczenia, ocena i implementacja osobista (Krížová, Brestovanský 2013, s. 147-150).

Istotna różnica między powyższą metodą wychowawczą i systemem prewencyjnym Jana Bosko polega na neutralności religijnej. Przyjęcie jej spowodowałoby bez wątpienia zubożenie myśli wychowawczej świętego z Turynu, a nawet ograbienie jej z elementu najistotniejszego, jakim jest religia.

\section{Psychologia pedagogiczna}

Istnieją paralele między systemem prewencyjnym Jana Bosko a niektórymi podejściami w psychologii pedagogicznej. Można je znaleźć np. w logoterapii Viktora Frankla, są to:

- Wsparcie źródeł osobistych młodego człowieka w procesie wzrostu (rozwoju).

- Jedność trójwymiarowa ciała, psychiki i ducha.

- Interpersonalna relacja między wychowawcą i wychowankiem.

- Osobowość wychowawcy jako niezastąpiony element procesu edukacji.

- Znaczenie środowiska wychowawczego $\mathrm{w}$ procesie osobistego dojrzewania (Kvašná 2011, s. 164-165).

Przedstawione powyżej próby reinterpretacji analizowanego systemu wychowawczego mają u podstaw praktyczne działania. Nie są więc tylko propozycjami teoretycznymi, lecz odzwierciedlają jego trwałe elementy, istotne dla dzisiejszej praktyki edukacyjnej na Słowacji.

\section{Dokumenty Rodziny Salezjańskiej}

Ostatnie zaprezentowane analizy odnośnie do teraźniejszości i przyszłości systemu prewencyjnego Jana Bosko na Słowacji to studium wybranych dokumentów dotyczących Rodziny Salezjańskiej. Do najważniejszych należy zaliczyć Zrewidowany projekt organiczny inspektorii salezjanów Księdza Bosko na Słowacji na lata 2010-2016, w którym wyznaczono następujące cztery priorytetowe kierunki działania:

1. „Wzrastać w jakości” - wymiar osobisty dotyczący życia duchowego i wzrostu zawodowego.

2. „Myśleć razem” - poziom społeczny wspólnot zakonnych i wychowawczo-duszpasterskich. Powierzanie odpowiedzialności za projekty edukacyjne także laikom.

3. „Dopomagać w dojrzewaniu” - postulat dotyczący animatorów i współpracowników, z którymi tworzymy wspólnotę wychowawczo-duszpasterską.

4. „Wychodzić do młodzieży w trudnych sytuacjach” - na poziomie projektów poszukujemy standardów pracy salezjańskiej z Romami. W większych miastach niektórzy salezjanie skupiają się na pracy z dziećmi ulicy (streetwork), 
od kilku lat podejmowane są działania zmierzające do przygotowania „domu w połowie drogi” dla chłopców, którzy zostali zwolnieni z zakładów karnych, ciągle rozwija się wolontariat misyjny i do pracy ze wspólnotą romską (Revidovaný Organický projekt provincie, s. 9-10).

Wspomniany projekt definiuje również wezwania dla salezjanów na lata 2013-2016. W ramach drugiego priorytetu („Myśleć razem”) konieczne jest rozwijanie współpracy ze świeckimi, w tym także w ramach innych grup Rodziny Salezjańskiej. Temu celowi służy zainicjowany niedawno projekt „Wizja 10”, w którym ogniskują się długofalowe rozważania nad przyszłością wspólnot salezjańskich. W ramach czwartego priorytetu („Wychodzić do młodzieży w trudnych sytuacjach”) zdiagnozowana została pilna potrzeba uczenia się dostrzegania prawdziwych potrzeb młodych ludzi w trudnych sytuacjach i dostosowywania do nich pracy salezjanów (Revidovaný Organický projekt provincie, s. 11, 14).

W Zrewidowanym projekcie organicznym inspektorii salezjanów Księdza Bosko na Słowacji na lata 2010-2016 zostały również uwypuklone dwa coraz silniejsze trendy:

1. Rosnąca obecność systemu prewencyjnego w szkołach (poprzez nauczanie i współpracę z wychowawcami i rodzicami).

2. Rozwój duszpasterstwa młodych rodzin w celu zastosowania systemu prewencyjnego Jana Bosko w relacjach rodzinnych (Revidovaný Organický projekt provincie, s. 15).

Do innych dokumentów Rodziny Salezjańskiej, które warte są przeanalizowania, należy zaliczyć Raport roczny Stowarzyszenia Salezjanów Wspótpracowników za rok 2015. Wymienia się w nim następujące projekty duszpasterskie, mające na celu wdrożenie systemu prewencyjnego Jana Bosko: „Szkoła animacji wspólnot rodzinnych”, kursy małżeńskie i wieczory dla rodziców, działalność animacyjna „Ojcowie i synowie”, jak również „Weekendy dla matek”, „Prewencyjny system wychowania mamy Małgorzaty” w rodzinie, osobisty udział członków ASC (Stowarzyszenia Salezjanów Współpracowników) na misjach (Združenie exallievov don Bosca..., s. 5, 9, 14, 19). Na podstawie analizy wybranych dokumentów Rodziny Salezjańskiej można stwierdzić, że proces stosowania systemu prewencyjnego Jana Bosko opiera się na osobistej relacji z Bogiem w stylu duchowości salezjańskiej („Wzrastać w jakości”). Proces rozeznawania współczesnych wyzwań (znaków czasu) odbywa się na poziomie wspólnotowym ze znacznym udziałem świeckich („Myśleć razem”). Trwałym wyzwaniem pozostaje młodzież znajdująca się w trudnych sytuacjach. Pomoc jej koncentruje się w następujących obszarach:

- Wspólnoty romskie i zagraniczne misje (szczególnie Jakuck i Azerbejdżan).

- Relacje między członkami rodziny (małżonkowie, dzieci - rodzice, nastolatki - rodzice).

- Dzieci i młodzież na ulicy.

Miejscem odkrywania trudności jest często środowisko szkolne. 
Członkowie Rodziny Salezjańskiej (SDB, FMA, ASC, VDB, byli wychowankowie) pracują w szkołach zarówno prywatnych, jak i publicznych. Ważnym elementem $\mathrm{w}$ realizacji systemu prewencyjnego w przyszłości będzie praca socjalna $\mathrm{z}$ dziećmi i młodzieżą, do której kwalifikują się młodzi salezjanie i współpracownicy.

\section{Podsumowanie}

Jaka jest specyfika systemu prewencyjnego Jana Bosko na Słowacji i jak można uaktualniać wychowanie w tym stylu w przyszłości? To pytania, które stanowią oś przestawionych powyżej rozważań. Na Słowacji da się zauważyć względnie wysoką liczbę osób (2392, o,044\%) przeżywających system prewencyjny Jana Bosko jako swoje codzienne doświadczenie człowieka konsekrowanego (zakonnika) lub laika (świeckiego). Młodzież salezjańska jest zrzeszona w wielu organizacjach młodzieżowych (DOMKA i LAURA), które oferują różnorodne formy pracy z młodymi ludźmi.

Tło antropologiczne obecnego środowiska edukacyjnego stanowi indywidualne zrozumienie człowieka i wynikająca $\mathrm{z}$ tego koedukacja zakorzeniona w relacjach rodzinnych. Postępująca w dzisiejszym społeczeństwie sekularyzacja prowadzi do konieczności podkreślania celu edukacyjnego: „dobry chrześcijanin i uczciwy obywatel”. Nowoczesny wyraz tej idei wyraża się w miłości do dzieci, wychowania i tworzenia współczesnego świata. Szczególnym wyrazem miłości jest poszukiwanie harmonii między duchowością i wychowaniem, duchowością i otwarciem się na świeckich, otwarciem się na Kościół i wiernością tożsamości salezjańskiej.

Doświadczenie pokazuje, że system prewencyjny Jana Bosko wykazuje podobieństwa do innych obszarów działalności, są to: w dydaktyce nauczania - korelacyjno-symboliczna metodyka kształcenia w katechezie i wychowanie prospołeczne Roberta Roche-Olivara; w psychologii - podejście logoterapeutyczne; w pracy socjalnej - praca ze wspólnotą romską. Pokazuje to, że implementacja systemu prewencyjnego księdza Bosko do innych obszarów środowiska społecznego jest możliwa i potrzebna, ponieważ wpływa na dojrzewanie relacji społecznych, a przez to również na dojrzewanie poszczególnych osób. Ważnym elementem w realizacji systemu prewencyjnego w przyszłości będzie praca socjalna z dziećmi i młodzieżą, do której kwalifikują się młodzi salezjanie i współpracownicy.

\section{Bibliografia}

Barillová A. (2014). Analýza saleziánskych diel pre mládež na Slovensku z perspektívy sociálnej práce. Bratislava: VŠZaSP sv. Alžbety.

Bešeney P. (2010). Dedičstvo dona Bosca a jeho využitie v rómskej misii. W: Bešeney P. (red.). Preventívny systém v rómskom svete. Medzinárodná konferencia o pastorácii Rómov. Bratislava: Vydavatel'stvo don Bosco, s. 41-49. 
Bešeney P. (2013). Preventívny systém a jeho uplatnenie pri segregačnom vzdelávaní Rómov. W: Kubík F., Kutarňa J. (red). Aktualizácia preventívneho systému $v$ dnešných časoch. Bratislava: VŠZaSP sv. Alžbety, s. 96-101.

Bosco J. (2012). Ďakovný list sv. Jána Bosca slovenskému dobrodincovi - november 1886. Bratislava: Saleziáni don Bosca - slovenská provincia.

Dejiny FMA na Slovensku. (2013). Saleziánky na Slovensku. Dcéry Márie Pomocnice FMA. Bratislava, dostępny na: <http://www.salezianky.sk/dejiny-fma-na-slovensku.html\#.VRUiB_mG-1U> (otwarty 31.03.2015).

Dove siamo. (2015). Volontari con don Bosco - CDB. Roma, dostępny na: <http:// www.volontaricdb.altervista.org/index.php?option=com_content\&view=artic le\&id=49\&Itemid=55\&lang=it $>$ (otwarty 31.03.2015).

DOMKA Výročná správa 2013. (2014). DOMKA - Združenie saleziánskej mládeže. Bratislava, dostępny na: < http://www.domka.sk/files/vyrocne-spravy/vs_domka-2013.pdf $>$ (otwarty 1.04.2015).

Fula M. (2013). Súčasné výzvy pre saleziánov v kontexte aktualizácie preventívneho systému. W: Kubík F., Kutarňa J. (red). Aktualizácia preventívneho systému $v$ dnešných časoch. Bratislava: VŠZaSP sv. Alžbety, s. 134-144.

Krížová O., Brestovanský M. (2013). Paralely výchovy kprosociálnosti so saleziánskym preventívnym systémom edukácie. W: Kubík F., Kutarňa J. (red). Aktualizácia preventívneho systému $v$ dnešných časoch. Bratislava: VŠZaSP sv. Alžbety, s. 145-152.

Kubík F. (2013). Volná čas ako výzva za čias dona Bosca a dnes. W: Kubík F., Kutarňa J. (red). Aktualizácia preventívneho systému $v$ dnešných časoch. Bratislava: VŠZaSP sv. Alžbety, s. 114-122.

Kvašná L. (2011). Koncepcia výchovného vztahu podla preventívneho systému dona Bosca logoterapeutického prístupu. W: Kutarňa J., Fula M. (red). Aktuálnost' logoterapie vo výchovnej a sociálnej práci s mládežou. Bratislava: VŠZaSP sv. Alžbety, s. 151-168.

Novák P. (2013). Ďakujeme don Bosco - Don Bosco na Slovensku. Saleziáni dona Bosca na Slovensku, dostępny na: <http://www.saleziani.sk/dakujeme-don-bosco> (otwarty 1.04.2015).

Piaček J., Kravčík M. (1999). Abdukcia. W: FILIT, Otvorená filozofický encyklopédia. Bratislava: Univerzita Komenského, dostępny na: <http://dai.fmph.uniba. sk/ kravcik/filit/pojem.php?obl=Abdukcia\&pobl=> (otwarty 31.03.2015).

Quanti siamo e dove siamo (Censimento anno 2011). (2011). Associazione Salesiani Cooperatori. Roma, dostępny na: <http://cooperatori.sdb.org/cooperatori/ quanti-siamo-e-dove-siamo--censimento-anno-2011-.html> (otwarty 31.03.2015).

Rajský A. (2013). Sekularita, laicita a saleziánska pedagogika. W: Kubík F., Kutarňa J. (red). Aktualizácia preventívneho systému v dnešných časoch. Bratislava: VŠZaSP sv. Alžbety, s. 33-42.

Reimer T. (2013). Korelatívna didaktika ako aplikácia edukačného preventívneho systému dona Bosca vo vyučovaní náboženstva na školách. W: Kubík F., Kutarňa J. 
(red). Aktualizácia preventívneho systému $v$ dnešných časoch. Bratislava: VŠZaSP sv. Alžbety, s. 69-81.

Revidovaný Organický projekt provincie (OPP) Saleziánov don Bosca na Slovensku na roky 2010-2016. (2013). Archív. Bratislava: Saleziáni don Bosca - slovenská provincia.

Saleziáni - Štatistické údaje (2014). Saleziáni don Bosca na Slovensku. Bratislava, dostępny na: $<$ http://www.saleziani.sk/kto-sme/statistiky> (otwarty 31.03.2015).

Saleziánska rodina (2013). Saleziáni don Bosca na Slovensku. Bratislava, dostępny na: <http://www.saleziani.sk/charakteristika-zloziek> (otwarty 31.03.2015).

Správa o stave provincie (roky 2010-2012). (2013). Archív. Bratislava: Saleziáni don Bosca - slovenská provincia.

Stav obyvatelstva $v$ SR $k$ 31. decembru 2014. (2015). Štatistický úrad slovenskej republiky. Bratislava, dostępny na: <http://slovak.statistics.sk/wps/portal/ext/ products/informationmessages/> (otwarty 1.04.2015).

Vojtáš M. (2013). Aktualizácia preventívneho systému. Propozitívne porovnanie rôznych modelov. W: Kubík F., Kutarňa J. (red). Aktualizácia preventívneho systému v dnešných časoch. Bratislava: VŠZaSP sv. Alžbety, s. 42-54.

Výročná správa ASC na Slovensku 2012-2015 (2015). Archív. Bratislava: Saleziáni don Bosca - slovenská provincia.

Združenie exallievov don Bosca na Slovensku. Bratislava (2015), dostępny na: $<$ http:// www.exallievi.sk/clenovia?sid=54> (otwarty 31.03.2015).

\title{
SLOVAKIAN PREVENTIVE EDUCATIONAL SYSTEM AS AN EDUCATIONAL APPROACH: THE PRESENT AND THE FUTURE
}

\begin{abstract}
Preventive educational system of St. John Bosco is visible in the lifestyle and the educational approach of Salesian family. The article deals with contemporary status and possible future (actualization) of its implementation in Slovakia. After the presentation of the current state of the structure and personnel of the Salesian Family, there are showed some theoretical studies on actualization of the preventive system in contemporary social life environments. The presentation of selected documents of the Salesian Family on the actualization of preventive system closes the reflections.
\end{abstract}

Key words: preventive educational system of St. John Bosco, Salesian family, application, actualization

Peter Mlynarčík - doktor filozofii, salezjanin. W swoich badaniach podejmuje problematykę filozoficznych aspektów nauk przyrodniczych, teologii i nauk socjalnych. Publikacja książkowa: Filozofia a veda v diele Josefa Tvrdého (2005). Adres do korespondencji: Gorkého 23, 01851 Nová Dubnica, Slovakia. Adres e-mail: mlynarcik@za.sanet.sk. 